> Gi respons på artikler gjennom artiklenes kommentarfelt på tidsskriftet.no.

Innleggene publiseres fortløpende på Tidsskriftets nettside og et utvalg

av innleggene publiseres også i papirutgaven i spalten «Brev til redaktøren».

Redaksjonen forbeholder seg retten til å foreta redaksjonelle endringer.

Forfattere av vitenskapelige artikler har tilsvarsrett, jf. Vancouver-gruppens regler.

I Tidsskriftet nr. 16/2016 sto det på trykk en kronikk av S. Moen og medarbeidere om bruk av MR-undersøkelse i diagnostikk og oppfølging av pasienter med multippel sklerose (1).

\section{Re: MR-undersøkelser ved multippel sklerose}

Takk for svar fra forfatteren på min kommentar. Vi er altså enige om at gadoliniumkontrast ikke skal gis uten en god indikasjon, da det er flere risikoer forbundet med dette. Problemet er at dette ikke fremkommer i kronikken, der man anbefaler intravenøs kontrast til alle pasienter ved rutinemessige kontroller.

De aller fleste tilkomne lesjoner vil ved en kontroll påvises med FLAIR-sekvenser. Dersom klinisk tilstand tilsier det, eller det er viktig for behandlingen om lesjonene er nyere enn 6-8 uker, kan intravenøs kontrast være nyttig. Ellers er det sjelden nødvendig å gi gadolinium ved rutinemessige kontroller av pasienter med multippel sklerose. I tillegg til tidligere nevnte toksiske effekter og risiko for allergiske reaksjoner er intravenøs kontrast ikke sjelden forbundet med andre bivirkninger (2), og tiden i MR-maskinen forlenges.

Retningslinjer for denne pasientgruppen bør gi klare begrunnelser for når intravenøs kontrast er nødvendig ved rutinekontroller, men også fraråde kontrastbruk når nytteverdien ikke rettferdiggjør risiko ved bruk av gadoliniumkontrast.

\section{Bjørn Einar Nielssen}

bjonie@so-hf.no

Bjørn Einar Nielssen (f. 1956) er overlege ved avdeling for bildediagnostikk ved Sykehuset Østfold.

Ingen oppgitte interessekonflikter.

\section{Litteratur}

1. Moen SM, Harbo HF, Sowa P et al. MR-undersøkelser ved multippel sklerose. Tidsskr Nor Legeforen 2016; 136: 1373-6.

2. Dotarem. Felleskatalogen. http://www.felleskatalogen.no/medisin/ dotarem-guerbet-548139 (6.10.2016).

\section{S.M. Moen og medarbeidere svarer:}

Vi vil igjen bekrefte at vi er enige med Bjørn Einar Nielssen i at gadoliniumkontrast ved MR-undersøkelse av nervesystemet ikke skal gis uten en god indikasjon, men vi må påpeke at per i dag er det ikke nok kunnskapsgrunnlag til generelt å fraråde bruk av kontrastundersøkelser ved slik undersøkelse. I diagnostikk og oppfølging av multippel sklerose har kontrastadministrasjon ved MR-undersøkelse av nervesystemet hatt utstrakt bruk i de fleste land i mange år, uten at det til nå er kommet rapporter om at dette er helseskadelig når man tar hensyn til allment kjente kontraindikasjoner. Ved multippel sklerose gir kontrastadministrasjon informasjon om aktiv betennelse, noe som er verdifullt ved vurdering og evaluering av sykdomsmodifiserende behandling. Derfor er bruk av kontrast også anbefalt $\mathrm{i}$ internasjonale retningslinjer for bruk av MR-undersøkelse ved multippel sklerose (1). Vi har som nevnt bidratt til ny forskning som viser tendens til gadoliniumavleiring etter bruk av lineære, men ikke makrosykliske kontrastmidler (2). Betydningen av dette funnet for pasientens helse er ennå ukjent, men våre funn gir grunnlag for å mane til forsiktighet ved bruk av lineære kontrastmidler, slik det fremgikk i vårt forrige svar til Nielssen. Vi er forberedt på at ny kunnskap kan medføre endring av retningslinjene, og eventuelle nye konkrete retningslinjer for bruk av kontrast ved diagnostikk og opp- følging av pasienter med multippel sklerose vil bli utarbeidet så snart kunnskapsgrunnlaget for dette foreligger.

\section{Stine Marit Moen \\ stinemaritm@gmail.com \\ Hanne Flinstad Harbo \\ Elisabeth Gulowsen Celius \\ Piotr Sowa \\ Gro Owren Nygaard \\ Mona K. Beyer}

Stine Marit Moen (f. 1971) er overlege ved nevrologisk avdeling, Oslo universitetssykehus.

Ingen oppgitte interessekonflikter.

Hanne Flinstad Harbo (f. 1963) er overlege ved Nevrologisk avdeling, Oslo universitetssykehus og professor ved Institutt for klinisk medisin, Universitetet i Oslo.

Ingen oppgitte interessekonflikter.

Elisabeth Gulowsen Celius (f. 1961) er seksjonsleder ved Nevrologisk poliklinikk, Nevrologisk avdeling, Oslo universitetssykehus og professor ved Institutt for helse og samfunn, Universitetet i Oslo.

Ingen oppgitte interessekonflikter.

Piotr Sowa (f.1968) er overlege ved Avdeling for radiologi og nukleærmedisin, Oslo universitetssykehus og ph.d-kandidat ved Institutt for klinisk medisin, Universitetet i Oslo.

Ingen oppgitte interessekonflikter.

Gro Owren Nygaard (f.1976) er lege i spesialisering ved Nevrologisk avdeling, Oslo universitetssykehus.

Ingen oppgitte interessekonflikter.

Mona K. Beyer (f. 1967) er overlege ved Avdeling for radiologi og nukleærmedisin, Oslo universitetssykehus og professor ved Avdeling for helsefag, Høgskolen i Oslo og Akershus.

Ingen oppgitte interessekonflikter.

\section{Litteratur}

1. Wattjes MP, Rovira À, Miller D et al; MAGNIMS study group. Evidence-based guidelines: MAGNIMS consensus guidelines on the use of MRI in multiple sclerosis - establishing disease prognosis and monitoring patients. Nat Rev Neurol 2015: 11: 597-606.

2. Lindland ES, Nabi S, Biernat D et al. T1 hyperintensity in the dentate nuclei of multiple sclerosis patients correlates with number of administrations and total dose of gadolinium based contrast agent. ECTRIMS Online Library. Beyer M. Sep 15, 2016; 146318. http://onlinelibrary.ectrims-congress.eu/ectrims/2016/32nd/ 146318/mona.k.beyer.t1.hyperintensity.in.the.dentate.nuclei.of.multiple. sclerosis.html?f=m2 (17.10.2016).

\section{Re: Ikke langvarig antibiotikabehandling ved sykdom tilskrevet borreliose}

Tidligere har jeg kommentert en redaksjonell omtale av en publikasjon fra Nederland om borreliosebehandling (1). I Tidsskriftet nr. 16/2016 er det gitt et tilsvar fra Randi Eikeland ved Nasjonal kompetansetjeneste for flåttbårne sykdommer (2). Jeg er selvsagt enig $i$ at pasienter som ikke har dokumentert eller sannsynliggjort borreliainfeksjon, ikke skal ha langvarig antibiotikabehandling. De skal ikke ha kortvarig heller. Mitt poeng er at studien som omtales 